UDC 615.322:547.913

\title{
COMPONENT COMPOSITION AND BIOLOGICAL ACTIVITY OF ESSENTIAL OILS OF GENUS DRACOCEPHALUM L.
}

\author{
(C) Ye.M. Suleimen ${ }^{I *}$, A.B. Myrzagaliyeva ${ }^{2}$,Zh.A. Ibatayev ${ }^{I}$,Zh.B. Iskakova ${ }^{I}$, T.N. Samarkhanov ${ }^{2}$, \\ B.Z. Medeubayeva ${ }^{2}$ \\ ${ }^{1}$ The Institute of Applied Chemistry, L.N. Gumilyov Eurasian National University, \\ K. Satbayev str., 2, Astana, 010008 (Republic of Kazakstan), \\ e-mail: suleimenem@enu.kz \\ ${ }^{2}$ S. Amanzholov East Kazakstan State University, 30-th Guards division str., 34, \\ Oskemen, 070019 (Republic of Kazakstan), e-mail: anara_vkgu@mail.ru
}

This article presents data on the study of the chemical composition, antiradical and cytotoxic activity of three species of the genus Dracocephalum L., which grow in East Kazakstan. Essential oils are obtained from aerial parts of plants D. nutans, D. ruyschiana, D. thymiflorum and the average yield of oil was $0,2 \%$. The chemical composition of essential oils were determined by the GC/MS.

Cytotoxic activity of essential oils was determined by the survival of Artemia salina aquatic crustaceans. Essential oils of D. nutans, D. ruyschiana and D. thymiflorum in all concentrations $(1-10 \mathrm{mg} / \mathrm{mL})$ tested exhibit acute lethal toxicity - all larvae were died. Antiradical activity was determined by the method based on colorimetry of free radicals (DPPH). The experimental results showed that essential oils from D. nutans, D. ruyschiana and D. thymiflorum at all tested concentrations $(0,1-1,0$ $\mathrm{mg} / \mathrm{mL}$ ) exhibited low antiradical activity compared with the standard drug - butylhydroxyanisole.

Keywords: Dracocephalum L., essential oils, chemical composition, GC/MS, cytotoxic activity, antiradical activity.

\section{Introduction}

The nature of East Kazakstan land is diverse and in many respects unique. The unique geographical position of the East Kazakstan region is that it is located in the depths of the largest continent of Eurasia within its central part, on the border of the Great Plains - Western Siberia, Central Asia and Kazakstan. In the territory of the region there is continental pole of the planet and the geographical center of Eurasia. East Kazakstan occupies the southwestern part of the Altai (Kazak Altai), Zaysan hollow, Kalba highlands, Saur-Tarbagatay ridges, Irtysh valley and eastern Kazak hills, it covers an area of 283,3 thousand $\mathrm{km}^{2}$. It is bordered on the North by Russia, on the East by China, on the South the border pass with Almaty, on the West - with the Pavlodar and Karaganda regions. On the

Suleimen Yerlan Melsuly - Candidate of Chem. Science, $\mathrm{PhD}$, Director of the Institute of Applied Chemistry, Associate Professor of Chemistry Department of L.N. Gumilev, e-mail: suleimen_em@enu.kz Myrzagaliyeva Anar Bazarovna - Doctor of biological sciences, Professor, Vice-rector for academic and educational work, e-mail: anara_vkgu@mail.ru Ibatayev Zharkyn Abykenovich - Candidate of Chem. Science, Leading Researcher of the Institute of Applied Chemistry, e-mail: ZharynAstana@gmail.com Iskakova Zhanar Baktybaevna - Candidate of Chem. Science, Leading Researcher of the Institute of Applied Chemistry, e-mail: zhanariskakova@mail.ru Samarkhanov Talant Nurzhakypovich - Master of geography, Senior Researcher, e-mail: talant.68@mail.ru Medeubayeva Balzhan Zaruetovna - Master of chemistry, Senior teacher of department of chemistry, e-mail: medeubayeva_bz@mail.ru territory of East Kazakstan is the law clear vertical zones of climate, vegetation and soils [1].

Dracocephalum L. (dragonhead) are widely distributed around the world. The genus includes about 70 species. In flora of East Kazakstan among the genuses of the family Lamiaceae the genus Dracocephalum occupies a leading position, including 9 species, representing $12 \%$ of the total number of species of the family Lamiaceae. Dracocephalum grow across all territory of East Kazakstan in various ecological conditions, rising up to $2500 \mathrm{~m}$ above sea level. They are part of the various phytocenoses [2]. The genus dragonhead (Dracocephalum) is widely distributed in the flora of East Kazakstan and is used in folk medicine. The aerial

\footnotetext{
${ }^{*}$ Corresponding author.
} 
part of dragonhead contains large amounts of essential oils, tannins, flavonoids, vitamins [3].

According Budantsev A.L. the genus includes about 70 species [2]. In "Flora of Kazakstan" (1964) described 22 species of this genus found on the territory of the Republic of Kazakstan [4].

To investigate we have been selected and collected plant materials of the following species of dragonhead: D. nutans L., D. ruyschiana L. and D. thymiflorum L.

Previously it was defined that the essential oil D. nutans consists of about 25 monoterpenoids, such as pinocamphone $(56,4 \%), \beta$-pinene $(12,7 \%)$, isopinocamphone $(4,3 \%), \alpha$-phellandrene $(4,6 \%)$ and isopinocampheol $(3,7 \%)[5]$.

The composition of essential oil of the Kazak species D. nutans is very different from the Indian species. It is indicated that the main components of the essential oil of the Kazakstan species D. nutans are decahydro-1,1,7trimethyl-4-methylene-1H-cycloprop[e]azulen-7-ol, (14,2\%), caryophyllene oxide (11,3\%), 3,7-dimethyl-1,6octadien-3-ol, (7,7\%), myrtenyl acetate (5,7\%), 1,2,3,4,4A,5,6,8A-octahydro-7-methyl-4-methylene-naphthalene (5,3\%), spathulenol (4,8\%), 1-methoxy-4-(1-propenyl)-benzene (4,7\%), decahydro-1,1,4,7-tetra-[ethenyl]-4ahcycloprop[e]azulen-4A-ol (4,7\%), germacrene D (4,4\%), 3(10)-caren-4-ol (4,2\%), 4,11,11-trimethyl-8-methulenebicyclo[7.2.0]undec-4-ene (3,7\%), $\alpha$-caryophyllene (3,6\%), 1,5,5,8-tetramethyl-12-oxabicyclo[9.1.0]dodeca-3,7diene $(2,1 \%)[6]$.

D. ruyschiana is cultivated in Baksa, Marosvásárhely/Tîrgu Mureş (Transylvania, Romania). The predominant compounds in the essential oil of D. ruyschiana $(0,2 \%)$ are oxygenated bicyclic monoterpenes, such as pinocamphone $(43,6 \%)$ and isopinocamphone $(21,5 \%)$. Besides the main components, also identified monoterpenes: myrcene $(3,1 \%)$, limonene $(0,7 \%)$, p-cymene $(1,5 \%)$ and $\beta$-pinene $(0,9 \%)$; sesquiterpenes: $\beta$ caryophyllene $(3,8 \%)$, caryophyllene oxide $(1,6 \%), \beta$-cubebene $(1,6 \%)$, germacrene-D $(3,6 \%)$ and elemol $(4,4 \%)$; and a phenylpropane: methyl chavicol $(0,6 \%)$. Pinocamphone and isopinocamphone also have been identified as main constituents of essential oil of D. nutans $[7,8]$.

The chemical composition and biological activity of essential oil of $D$. thymiflorum or Moldavica thymiflora is poorly investigated, according to the database of Dr. Duke main components of the essential oil of $D$. thymiflorum are pulegone, caryophyllene, isomenthone, $\beta$-elemene and 1,8-cineole [9].

\section{Experimental}

Plant material. For study the chemical composition and biological activity of essential oils, we have collected vegetable raw materials of three types of dragonhead: Dracocephalum nutans, D. ruyschiana, D. thymiflorum.

D. nutans - rhizomatous perennial. It grows in forests, shrubby thickets, on gravelly, sandy and rocky slopes, taluses and steppe pastures, often comes up to the timber line [4]. The plant for research was collected in the territory of East Kazakstan, Katon-Karagay district, the neighborhood of the village Enbek, the mountain Shagyl (N 49 $12,200^{\prime}$; E $086^{\circ} 10,320^{\prime}$ at the height of $990 \mathrm{~m}$ above sea level).

D. ruyschiana - a puberulent perennial plant with height 20-60 cm. It blossoms in the summer, in JuneJuly, fruiting in July-August [4]. Samples of plants were also collected in the territory of East Kazakstan, in KatonKaragay district, on the ridge Sarymsakty, tract Akimbay (N 49 $12,407^{\prime}$; E 086 $11,415^{\prime}$ at the height of $1383 \mathrm{~m}$ above sea level).

D. thymiflorum - an annual plant 15-50 cm high. It grows in bushes, on edges of forests, often as thicket of weed on raw farm lands [4]. The plant was collected in the East Kazakstan region, in Katonkaragay District, on the rocky slopes of the ridge Sarymsakty, along the road to the pass Burhat (N 49 $09,617^{\prime}$; E $086^{\circ} 02,198^{\prime}$ at the height of $1012 \mathrm{~m}$ above sea level).

All plants were collected in the second decade of July, 2014. Plant samples are stored in the herbarium of the Department of Biology of the S. Amanzholov East Kazakstan State University (Oskemen).

Extraction of essential oil. Essential oils were obtained from dried, crushed aerial parts of plants $(\sim 100 \mathrm{~g})$ by steam distillation in a Clevenger apparatus for $3 \mathrm{~h}$ according to the method by the Pharmacopoeia [10]. During receiving essential oil used hexane as a trap. The essential oil was collected by decantation, dried over $\mathrm{Na}_{2} \mathrm{SO}_{4}$, weighed and stored in sealed dark glass vials at $4-5^{\circ} \mathrm{C}$ until analysis.

The yields for all samples averaged $0,1 \%$. 
Analytical GC. The constituent composition of essential oils were determined on a Clarus-SQ 8 GC/MS (PerkinElmer) with a mass-spectrometric detector. An essential oil sample $(25 \mathrm{mg})$ was placed into a $25-\mathrm{mL}$ volumetric flask, dissolved in hexane $(15 \mathrm{~mL})$, adjusted to the mark, and stirred until the oil was fully mixed.

Chromatographic conditions: capillary column Restek Rxi ${ }^{\circledR}-1 \mathrm{~ms}(0,25 \mathrm{~mm} \times 30 \mathrm{~m} \times 0,25 \mu \mathrm{m})$; sample volume $1,0 \mu \mathrm{L}$; He carrier gas at $1 \mathrm{~mL} / \mathrm{min}$; flow division $1: 25$; column temperature $45^{\circ} \mathrm{C}$ increasing at $1,5^{\circ} \mathrm{C} / \mathrm{min}$ to $200^{\circ} \mathrm{C}$, than at $15^{\circ} \mathrm{C} / \mathrm{min}$ to $280^{\circ} \mathrm{C}$ and isotherm at $280^{\circ} \mathrm{C}$ for $10 \mathrm{~min}$; vaporizer temperature $280^{\circ} \mathrm{C}$; mass spectrometric detector at $240{ }^{\circ} \mathrm{C}$ with EI $+70 \mathrm{eV}$; scan time 4-120 min; scan range 39-500 m/z.

The percent contents of constituents were calculated automatically from peak areas in the total ion chromatogram. Constituents were identified from mass spectra and retention times, using the NIST library. Retention indices were calculated relative to $n$-alkanes.

Cytotoxic activity. Separating funnel filled with $55 \mathrm{~mL}$ of artificial sea water and $200 \mathrm{mg}$ of Artemia salina eggs. Allowed standing for 3 days at the air supply until soft crustaceans gave the egg. One side of the tube covered with aluminum foil, and 5 minutes later, the larvae that are going on the bright side of the funnel, removed with Pasteur pipette.

20-40 larvae were placed in $990 \mu \mathrm{L}$ of seawater into each of the 24 micro titer plates. Dead larvae were counted using a microscope. Added $10 \mu \mathrm{L}$ of dimethylsulfoxide solution of $10 \mathrm{mg} / \mathrm{mL}$ sample. As a comparison, the drug actinomycin D or staurosporine was used. For a negative control $10 \mu \mathrm{L}$ was added only DMSO. After 24 $\mathrm{h}$ of incubation and further maintaining micro titer plates for 24 hours (to ensure immobility) counts the dead larvae by the microscope [11].

Mortality P determined by the following formula:

$$
P=\frac{A-N-B}{Z} 100 \%
$$

$P=\frac{A-N-B}{Z} 100 \%$ Where A - amount of dead larvae after $24 \mathrm{~h} ; \mathrm{N}-$ amount of larvae died before the test; $\mathrm{B}-$ the average amount of larvae died in a negative control; $\mathrm{Z}$ - the total amount of larvae.

Antiradical activity. Determination of antiradical activity of essential oil was carried out by the known technique of the colorimetry of free radicals based on reaction of the radical a 2,2-diphenyl-1-picrylhydrazil (DPPH) with standard of antioxidant $[12,13]$.

For determination of inhibition of DPPH to $0,1 \mathrm{~mL}$ of the test sample in the range of concentration of 0,25 ; 0,$5 ; 0,75 ; 1 \mathrm{mg} / \mathrm{mL}$ added $3 \mathrm{ml}$ of $6 \times 10^{-5} \mathrm{M}$ solution of radical. Centrifuge test tubes were in a support, wrapped in black polyethylene. After intensive mixing, solutions were left in the dark and after 30 minutes were measured absorbance of solutions at $520 \mathrm{~nm}$.

The values of antiradical activity (ARA) were calculated using the formula shown below:

$$
\operatorname{ARA}(\%)=\left(A_{0}-A_{t}\right) / A_{0} * 100 \%
$$

Where $\mathrm{A}_{0}$ - absorbance of control; $\mathrm{A}_{\mathrm{t}}$ - absorbance of the working sample.

The optical density of the investigated samples measured on a spectrophotometer Cary 60 UV-Vis. Antiradical activity of essential oil, we compared with butylhydroxyanisole (BHA).

Antiradical activity is defined in relation to standard - of butylhydroxyanisole (BHA).

\section{Results and Discussion}

Chemical composition . As shown in the Table 1, in essential oil of D. nutans mail components are: cis, cisnepetalactone $-35,0 \%$, germacrene $\mathrm{D}-6,3 \%, \beta$-cyclocitral $-4,0 \%, \beta$-bourbonene $-3,1 \%$ and cis, transnepetalactone $-2,9 \%$. The main components of the essential oil of $D$. ruyschiana found $\alpha$-pinene $-3,8 \%, 3$-carene $-3,2 \%, \beta$-pinene $-2,7 \%$ and 3-octanol acetate $-2,5 \%$, and in essential oil of D. thymiflorum - $\beta$-caryophyllene oxide $-12,2 \%$, spathulenol $-9,4 \%$, palustrol $-3,9 \%, 1,8$-cineol $-3,7 \%$ and humulene-1,2-epoxide $-3,7 \%$.

Cytotoxic activity. Results of the study the cytotoxic activity of essential oils from areal parts of D. nutans, D. ruyschiana and D. thymiflorum are shown in Tables 2-4.

Based on this experiment it can be assumed that the essential oils of D. nutans, D. ruyschiana and D. thymiflorum in all concentrations tested exhibit acute lethal toxicity - all larvae are died. 
Antiradical activity. Values of the antiradical activity of essential oils of D. nutans, D. ruyschiana and D. thymiflorum calculated by the formula (2) are given in Table 5.

The experimental results showed that essential oils of D. nutans, D. ruyschiana and D. thymiflorum at all tested concentrations exhibited low antiradical activity compared with the reference drug butylhydroxyanisole.

Table 1. Chemical composition of the aerial parts essential oils of D. nutans, D. ruyschiana and D. thymiflorum

\begin{tabular}{|c|c|c|c|c|}
\hline \multirow{2}{*}{ RI } & \multirow{2}{*}{ Compound } & \multicolumn{3}{|c|}{ Composition (\%) } \\
\hline & & D. nutans & D. ruyschiana & D. thymiflorum \\
\hline 1 & 2 & 3 & 4 & 5 \\
\hline 781 & Hexanal & - & 1,6 & 1,1 \\
\hline 819 & 2-Hexenal & - & 0,6 & - \\
\hline 921 & Benzaldehyde & - & 0,4 & - \\
\hline 924 & $\alpha$-Pinene & 0,8 & 3,8 & 0,8 \\
\hline 959 & $\beta$-Pinene & 0,4 & 2,7 & 0,8 \\
\hline 960 & 1-Octen-3-ol & 1,0 & - & - \\
\hline 962 & 6-Methylheptan-3-on & - & 0,6 & - \\
\hline 973 & 2-Pentyl- furan & - & - & 0,4 \\
\hline 980 & $\beta$-Myrcene & 0,6 & 2,1 & 1,0 \\
\hline 997 & 3-Carene & - & 3,2 & 0,7 \\
\hline 997 & $\alpha$-Ocimene & 1,0 & - & - \\
\hline 1001 & Benzeneacetaldehyde & - & 1,0 & 0,6 \\
\hline 1006 & $o$-Cymene & - & 0,7 & - \\
\hline 1012 & 1,8-Cineol & 0,5 & 1,9 & 3,7 \\
\hline 1014 & Limonene & - & 0,4 & 0,9 \\
\hline 1014 & 3-Ethyl-4,5-dimethyl-1,4-hexadiene & 0,6 & - & - \\
\hline 1025 & cis- $\beta$-Ocimene & 1,3 & - & - \\
\hline 1035 & trans- $\beta$-Ocimene & 0,3 & - & - \\
\hline 1080 & Nonanal & - & 0,7 & - \\
\hline 1081 & Linalool & 0,6 & 1,1 & 2,1 \\
\hline 1094 & 3,4-Diethylthiophene & 1,5 & 0,8 & - \\
\hline 1111 & 3-Octanol acetate & - & 2,5 & - \\
\hline 1124 & Pinocarvone & 0,3 & 1,5 & 0,4 \\
\hline 1133 & Isopinocamphone & - & - & 0,4 \\
\hline 1134 & trans-Pinocamphone & 0,3 & 1,0 & - \\
\hline 1138 & Cryptone & - & - & 2,2 \\
\hline 1140 & Naphthalene & 0,4 & 1,9 & - \\
\hline 1148 & Terpinen-4-ol & - & 0,5 & - \\
\hline 1153 & Myrtenal & - & 0,5 & - \\
\hline 1159 & $\alpha$-Terpineol & - & 0,9 & 0,6 \\
\hline 1172 & $\beta$-Cyclocitral & 4,0 & - & - \\
\hline 1191 & $p$-Ethylbenzyl alcohol & 0,4 & - & - \\
\hline 1193 & $p$-Cumic aldehyde & - & - & 1,4 \\
\hline 1194 & 5,5-Dimethyl-2-propyl-1,3-cyclopentadiene & 0,4 & - & - \\
\hline 1196 & Pulegone & - & 1,4 & 0,6 \\
\hline 1209 & cis-3-Hexenyl- $\alpha$-methylbutyrate & - & - & 1,2 \\
\hline 1214 & cis-3-Hexenyl isovalerate & 0,3 & - & - \\
\hline 1229 & Phellandral & - & - & 0,5 \\
\hline 1233 & cis-Chrysanthenyl acetate & - & - & 0,5 \\
\hline 1257 & Isocarveol & - & 0,5 & - \\
\hline 1263 & Dihydroedulan II & 2,0 & - & - \\
\hline 1295 & n-Nonyl acetate & - & 0,4 & - \\
\hline 1295 & Myrtenyl acetate & - & - & 0,9 \\
\hline 1305 & p-Methoxy thiophenol & 0,9 & 0,6 & - \\
\hline 1306 & cis, cis-Nepetalactone & 35,0 & 0,5 & 0,4 \\
\hline 1319 & Eugenol & - & 0,5 & - \\
\hline 1332 & cis, trans-Nepetalactone & 2,9 & 1,3 & 1,8 \\
\hline 1350 & trans- $\beta$-Damascenone & - & 0,4 & - \\
\hline 1355 & cis-Jasmone & 0,3 & - & - \\
\hline 1359 & $\alpha$-Copaene & 0,5 & - & - \\
\hline 1364 & $\beta$-Bourbonene & 3,1 & 0,5 & 2,3 \\
\hline 1373 & $\beta$-Elemene & - & - & 0,6 \\
\hline
\end{tabular}


End of Table 1

\begin{tabular}{|c|c|c|c|c|}
\hline 1 & 2 & 3 & 4 & 5 \\
\hline 1376 & $\alpha$-Dihydroionone & 0,3 & - & - \\
\hline 1395 & $\beta$-Caryophyllene & 1,1 & - & 0,7 \\
\hline 1396 & Aristolene & - & 0,6 & - \\
\hline 1406 & $\beta$-Copaene & 0,6 & - & - \\
\hline 1422 & Geranyl acetone & - & 0,8 & - \\
\hline 1440 & trans $-\beta$-Farnesene & 1,4 & - & - \\
\hline 1446 & trans- $\beta$-Ionone & 0,3 & 1,8 & 0,5 \\
\hline 1450 & Germacrene D & 6,3 & 0,4 & 1,1 \\
\hline 1455 & $\alpha$-Curcumene & 0,6 & - & - \\
\hline 1460 & $\gamma$-Muurolen & 0,7 & - & - \\
\hline 1464 & Bicyclogermacrene & - & - & 0,4 \\
\hline 1464 & $\delta$-Guaiene & - & - & 0,4 \\
\hline 1470 & Unknown 1 & - & 0,5 & - \\
\hline 1471 & $\alpha$-Cedrene & 0,8 & - & - \\
\hline 1471 & Cubebol & - & - & 0,4 \\
\hline 1479 & $\gamma$-Cadinene & 0,5 & - & - \\
\hline 1480 & $\beta$-Bisabolene & 1,3 & - & - \\
\hline 1491 & $\delta$-Cadinene & 2,0 & - & - \\
\hline 1500 & Pentadecane & - & - & 0,4 \\
\hline 1503 & Norbourbonone & - & - & 0,5 \\
\hline 1505 & Caryophyllene oxide isomer & - & - & 0,7 \\
\hline 1521 & 1,5-Epoxysalvial-4(14)-ene & - & - & 0,5 \\
\hline 1528 & Palustrol & - & - & 3,9 \\
\hline 1533 & Spathulenol & 0,3 & - & 9,4 \\
\hline 1538 & $\beta$-Caryophyllene oxide & 1,0 & 0,6 & 12,2 \\
\hline 1541 & $\beta$-Spathulenol & - & - & 0,8 \\
\hline 1547 & Isoaromadendrene epoxide & 0,5 & - & 0,4 \\
\hline 1547 & Salvial-4(14)-en-1-one & 0,3 & - & - \\
\hline 1553 & Aromadendrene oxide-(2) & - & - & 0,4 \\
\hline 1563 & $\alpha$-Guaiol & 1,0 & 2,3 & - \\
\hline 1564 & Humulene-1,2-epoxide & - & - & 3,7 \\
\hline 1590 & Isospathulenol & - & - & 1,7 \\
\hline 1600 & Hexadecane & - & - & 0,6 \\
\hline 1618 & $\delta$-Cadinol & - & - & 0,5 \\
\hline 1633 & Bulnesol & 0,9 & 2,4 & - \\
\hline 1635 & (1R,7S,E)-7-Isopropyl-4,10-dimethylenecyclodec-5-enol & - & - & 2,1 \\
\hline 1646 & ent-Germacra-4(15),5,10(14)-trien-1 $\beta$-ol & 0,6 & - & - \\
\hline 1649 & Unknown 2 & - & 0,8 & 1,1 \\
\hline 1824 & Phthalic acid, isobutyl octyl ester & - & 0,7 & 0,5 \\
\hline 1835 & Perhydrofarnesyl acetone & 0,3 & 0,6 & 0,6 \\
\hline 1949 & $n$-Hexadecanoic acid & 0,5 & 1,2 & 0,7 \\
\hline 2066 & Biformen & 0,3 & - & - \\
\hline 2097 & trans-Phytol & 0,4 & 0,7 & - \\
\hline 2346 & Larixol & 0,5 & - & - \\
\hline 2700 & $n$-Heptacosane & 0,4 & - & - \\
\hline 2900 & $n$-Nonacosane & - & 0,9 & 0,5 \\
\hline
\end{tabular}

Table 2. Cytotoxic activity of essential oil from areal parts of D. nutans

\begin{tabular}{|c|c|c|c|c|c|c|c|c|c|}
\hline \multirow{2}{*}{ Parallel } & \multicolumn{2}{|c|}{$\begin{array}{c}\text { Number of larvae } \\
\text { in control }\end{array}$} & \multicolumn{3}{|c|}{ Number of larvae in sample } & \multirow{2}{*}{$\begin{array}{l}\text { The amount } \\
\text { of surviving } \\
\text { larvae in the } \\
\text { control, \% }\end{array}$} & \multirow{2}{*}{$\begin{array}{c}\text { The amount } \\
\text { of surviving } \\
\text { larvae in } \\
\text { sample, \% }\end{array}$} & \multirow{2}{*}{$\begin{array}{l}\text { Mor- } \\
\text { tality, } \\
\mathrm{P}, \%\end{array}$} & \multirow{2}{*}{$\begin{array}{c}\text { The } \\
\text { percentage of } \\
\text { neurotoxicity, } \\
\%\end{array}$} \\
\hline & survived & died & survived & died & paralyzed & & & & \\
\hline \multicolumn{10}{|c|}{$10 \mathrm{mg} / \mathrm{mL}$} \\
\hline Medium & 25 & 1 & 0 & 28 & 0 & 96 & 0 & 96 & 0 \\
\hline \multicolumn{10}{|c|}{$5 \mathrm{mg} / \mathrm{mL}$} \\
\hline Medium & 25 & 1 & 0 & 27 & 0 & 96 & 0 & 96 & 0 \\
\hline \multicolumn{10}{|c|}{$1 \mathrm{mg} / \mathrm{mL}$} \\
\hline Medium & 25 & 1 & 0 & 27 & 0 & 96 & 0 & 96 & 0 \\
\hline
\end{tabular}


Table 3. Cytotoxic activity of essential oil from areal parts D. ruyschiana

\begin{tabular}{|c|c|c|c|c|c|c|c|c|c|}
\hline \multirow{2}{*}{ Parallel } & \multicolumn{2}{|c|}{$\begin{array}{l}\text { Number of larvae } \\
\text { in control }\end{array}$} & \multicolumn{3}{|c|}{ Number of larvae in sample } & \multirow{2}{*}{$\begin{array}{l}\text { The amount } \\
\text { of surviving } \\
\text { larvae in the } \\
\text { control, } \%\end{array}$} & \multirow{2}{*}{$\begin{array}{c}\text { The amount } \\
\text { of surviving } \\
\text { larvae in } \\
\text { sample, \% }\end{array}$} & \multirow{2}{*}{$\begin{array}{l}\text { Mor- } \\
\text { tality, } \\
\mathrm{P}, \%\end{array}$} & \multirow{2}{*}{$\begin{array}{c}\text { The } \\
\text { percentage of } \\
\text { neurotoxicity, } \\
\%\end{array}$} \\
\hline & survived & died & survived & died & paralyzed & & & & \\
\hline \multicolumn{10}{|c|}{$10 \mathrm{mg} / \mathrm{mL}$} \\
\hline Medium & 25 & 1 & 0 & 23 & 0 & 96 & 0 & 96 & 0 \\
\hline \multicolumn{10}{|c|}{$5 \mathrm{mg} / \mathrm{mL}$} \\
\hline Medium & 25 & 1 & 0 & 24 & 0 & 96 & 0 & 96 & 0 \\
\hline \multicolumn{10}{|c|}{$1 \mathrm{mg} / \mathrm{mL}$} \\
\hline Medium & 25 & 1 & 0 & 25 & 0 & 96 & 0 & 96 & 0 \\
\hline
\end{tabular}

Table 4. Cytotoxic activity of essential oil from areal parts D. thymiflorum

\begin{tabular}{|c|c|c|c|c|c|c|c|c|c|}
\hline \multirow{2}{*}{ Parallel } & \multicolumn{2}{|c|}{$\begin{array}{l}\text { Number of larvae } \\
\text { in control }\end{array}$} & \multicolumn{3}{|c|}{ Number of larvae in sample } & \multirow{2}{*}{$\begin{array}{l}\text { The amount } \\
\text { of surviving } \\
\text { larvae in the } \\
\text { control, } \%\end{array}$} & \multirow{2}{*}{$\begin{array}{c}\text { The amount } \\
\text { of surviving } \\
\text { larvae in } \\
\text { sample, \% }\end{array}$} & \multirow{2}{*}{$\begin{array}{l}\text { Mor- } \\
\text { tality, } \\
\mathrm{P}, \%\end{array}$} & \multirow{2}{*}{$\begin{array}{c}\text { The } \\
\text { percentage of } \\
\text { neurotoxicity, } \\
\%\end{array}$} \\
\hline & survived & died & survived & died & paralyzed & & & & \\
\hline \multicolumn{10}{|c|}{$10 \mathrm{mg} / \mathrm{mL}$} \\
\hline Medium & 25 & 1 & 0 & 28 & 0 & 96 & 0 & 96 & 0 \\
\hline \multicolumn{10}{|c|}{$5 \mathrm{mg} / \mathrm{mL}$} \\
\hline Medium & 25 & 1 & 0 & 25 & 0 & 96 & 0 & 96 & 0 \\
\hline \multicolumn{10}{|c|}{$1 \mathrm{mg} / \mathrm{mL}$} \\
\hline Medium & 25 & 1 & 0 & 28 & 0 & 96 & 0 & 96 & 0 \\
\hline
\end{tabular}

Table 5. Antiradical activity of various concentrations of essential oils from D. nutans, D. ruyschiana and D. thymiflorum, \%

\begin{tabular}{c|l|c|c|c|c|c}
\hline \multirow{2}{*}{ No Sample } & \multicolumn{5}{|c}{ Essential oil concentration, $\mathrm{mg} / \mathrm{mL}$} \\
\cline { 3 - 7 } & & 0,1 & 0,25 & 0,5 & 0,75 & 1,0 \\
\hline 1 & Butylhydroxyanisole (BHA) & 80,82 & 81,23 & 80,30 & 83,08 & 83,88 \\
2 & Dracocephalum nutans L. & 5,53 & 6,46 & 6,59 & 7,79 & 7,32 \\
3 & Dracocephalum ruyschiana L. & 3,51 & 4,57 & 3,89 & 4,97 & 4,26 \\
4 & Dracocephalum thymiflorum L. & 5,65 & 7,57 & 7,83 & 8,64 & 8,70 \\
\hline
\end{tabular}

\section{Conclusion}

Thus, during the researches the chemical composition, cytotoxic and antiradical activity of essential oils from D. nutans, D. ruyschiana and D. thymiflorum were determined.

The experimental data show that the essential oils of D. nutans, D. ruyschiana and D. thymiflorum showed high cytotoxic and low antiradical activities.

\section{References}

1. Egorina A.V., Zinchenko Yu.K., Zinchenko E.S. Physical geography of the Eastern Kazakstan. Oskemen, 2002, 182 p. (in Russ.).

2. Budantsev A.L. Species of the genus Dracocephalum L. flora of the USSR: systematics, geography, possibilities of use. PhD Thesis. St. Petersburg, 1987, 23 p. (in Russ.).

3. Recipes of traditional medicine [Internet]. URL: http://nmedic.info/story/zmeegolovnik. (in Russ.).

4. Pavlov N.V. Flora of Kazakstan. Almaty, 1964, vol. 7, 515 p. (in Russ.).

5. Misra L.N., Shawl A.S., Raina V.K. Planta Med., 1988, vol. 54, pp. 165-166.

6. Baiseitova A.M., Aisa H., Jenis J. International Journal of Biology and Chemistry, 2015, vol. 8, pp. 90-97.

7. Kakasy A.Z. New phytochemical data on Dracocephalum species. Ph.D Thesis. Budapest, 2006, 14 p.

8. Lemberkovics E., Kakasy A.Z., Héthelyi B.E., Simándi B., Böszörményi A., Balázs A., Szoke E. Acta Pharm Hung, 2007, vol. 77, pp.19-27.

9. Dr. Duke's Phytochemical and Ethnobotanical Databases [Internet]. U.S. Department of Agriculture, Agricultural Research Service. http://phytochem.nal.usda.gov.

10. State Pharmacopoeia of the USSR, no. 1, General Analytical Methods. Medicinal Plant Raw Material. $11^{\text {th }}$ ed., MH USSR, Moscow, 1990. pp. 290-295. (in Russ.).

11. Suleimen E.M. Chem. Nat. Compd., 2009, vol. 45, p. 710.

12. Sawant O., Kadam V.J., Ghosh R. Journal of Herbal Medicine and Toxicology, 2009, vol. 3, pp.39-44.

13. Sisengalieva G.G., Suleimen E.M., Ishmuratova M.Yu., Iskakova Zh.B., Van Hecke K. Chem. Nat. Compd., 2015, vol. 51, pp. 544-547. 